\title{
Development and Performance Evaluation of Tractor Drawn Turmeric Digger cum Separator
}

\author{
Shailaja Deshvena*, R.T. Ramteke and S.N. Solanki \\ Department of Farm Machinery \& Power Engineering, College of Agricultural Engineering, \\ Parbhani, V.N.M.K.V. Parbhani. (Maharashtra State), India \\ *Corresponding author
}

\section{Keywords}

Performance,

Tractor, Digger cum

Separator, Field

capacity

Article Info

Accepted:

10 January 2019

Available Online:

10 February 2019

\section{A B S T R A C T}

The tractor drawn turmeric digger cum separator was developed with an objective to have mechanical means for harvesting of turmeric crop. The components were designed and developed keeping in view of objective crop, soil and machine parameters. The machine consisted of a main frame, digging blade, depth gauge wheel, power transmission system, and conveying mechanism. The performance evaluation of developed machine was evaluated at Khanapur village Parbhani district of Maharashtra State. The experiment was undertaken in black cotton soil; the range of observed moisture content was 12.23 to 16.28 percent moisture content $(\mathrm{db})$ at the time of harvesting. The size of the experiment plot was 0.5 ha was taken for observations. During field testing of machines, draft, digging efficiency, per cent damage of turmeric rhizome and fuel consumption, separation index and power requirement were calculated. The field capacity was also measured. The turmeric digger cum separator was tested at three different shapes of digging blades and at three different levels of forward speed i.e. 1.5, 3.0 and $4.5 \mathrm{~km} \mathrm{~h}^{-1}$. The draft and power requirement for harvesting turmeric digger cum separator was found to be draft $2199 \mathrm{~N}$ and Power requirement $0.91 \mathrm{~kW}$ respectively. Fuel consumption for particular operation was observed to be $6.121 \mathrm{~h}^{-1}$.The field capacity of turmeric digger cum separator was calculated $0.47 \mathrm{ha} \mathrm{h}^{-1}$. The digging efficiency, damage of rhizome and separation index of turmeric digger cum separator was recorded to be 97.35 ha hr 3.34 per cent and 0.24 per cent.

\section{Introduction}

Turmeric is also called as "The Golden Spice "and "Indian Saffron" (Devi and Sangamithra, 2011). Turmeric botanically known as Curcuma longa L. (Syn. Curcuma domestica) belongs to the family Zingiberaceae is one of the most important and ancient spices of India and a traditional item of export, which is used daily. Botanist, Valeton coined the name Curcuma domestica (Anon., 2007). The word Curcuma, is derived from the Arabic "kurkum" and from the Hebrew "karkom" which means "yellow". The term longa refers to the elongated shape of its rhizome. It contains appreciable quantities of proteins (8.6\%), fats $(8.9 \%)$, mineral matters $(6.8 \%)$ carbohydrates $(63.0 \%)$, Vitamin A (175 
IU/100g), Sodium (0.01\%), Potassium (2.5\%) and fibre (6.9\%) (Parthasarathy and Kandiannan, 2007).

Apart from nutritional advantages the demand of turmeric is due to its property of colouring and flavouring of cooked stuff. These sensory properties of turmeric are due to the presence of curcumin and essential oil which is generally present in the turmeric rhizome.

India is the largest producer, consumer and exporter of turmeric in the world. Indian turmeric is considered the best in the world market because of its high curcumin content (Devi and Sangamithra, 2011) India dominates the world production scenario contributing $78 \%$ followed by China (8\%), Myanmar (4\%) and Nigeria and Bangala Desh together contributing to $6 \%$ of the global production. India is the global leader in value added products of turmeric and exports.).

The main turmeric producing states in India are Telangana, Andhra Pradesh, Tamilnadu, Maharashtra, Orissa, West Bengal, Karnataka, Kerala. In the year 2017-18 Maximum area under turmeric cultivation is in Telangana (50.00 thousand ha), where production is very high i.e. 294.00 thousand tones. Then comes Maharashtra, Tamilnadu, Orissa and West Bengal, Assam, Mizoram. In case of production major share is taken by Andhra Pradesh accounted to $31.11 \%$ of total turmeric production in India, followed by Tamilnadu. In Tamilnadu, turmeric is cultivated in about 67246 ha with production of about 368411 tons with average productivity of $5.48 \mathrm{t} / \mathrm{ha}$.

Kadte (2017) studied on economics of turmeric production in Maharashtra and concluded that Turmeric production in India has shown a fluctuating trend in last five years. It was 43000 tones in 2011-12, and increased to 65000 tones in 2012-13. Again decreased to 37000 tones in 2013-14 and then increased to 70000 tones in 2014-15. The annual turmeric production was 48500 tones in 2015-16. Hence price of turmeric is not fixed and tend to fluctuate year by year. Maharashtra state in India ranks sixth in area under turmeric cultivation. The area under crop was 11000 hectare with a production of 45000 tones and productivity of 4.09 tonnes/hectare during 2015-16. In Maharashtra Sangali, Satara, Hingoli, Nanded, Parbhani are the major turmeric growing districts. It is one of the major crop in Sangali district. In Sangali the area under turmeric is 1500 hectares, whereas production and productivity is 13000 tonnes and 8.6 tonnes /hectare, respectively in 2015-16.

Harvesting is one of main important operation in turmeric cultivation. In India, it is performed by manual method with the help of hand tools i.e., special fork type of spade/ pick axe, bullock drawn and power operated devices and by using traditional diggers drawn by tractors or power tillers. It was found that there is a noticeable damage to the crop during harvesting. However, most of the digging operation during turmeric harvesting is done manually due to non availability of suitable devices.

The post harvest studies of turmeric indicated that, about 70 per cent of the rhizomes are spoiled and wasted due to the storage rots caused by rough harvesting and handling practices resulting in injury of skin and flesh of the rhizomes (Rattan et al., 1988).

Sometimes, bullock operated wooden plough is also used for tuber crop harvesting. These conventional methods need more labour with less field capacity which increases cost of operation. On an average, about 600 man-h of labour per hectare is required for harvesting of root crops manually (Sharma and Varma 1986). This method of harvesting is highly labour intensive, tedious and time consuming. 
It is also a very difficult task on the part of farmer to get required labour force during the harvesting season for the timely harvesting of crop. To alleviate all this, there is a need to develop a suitable mechanical harvesting technology for turmeric crops. The mechanization of turmeric harvesting is need of the hour as it saves harvesting time, cost of harvesting, crop damage and reduce drudgery involved. Keeping in view of the above points in mind, the present study was undertaken with the objective of development and performance evaluation of tractor drawn turmeric digger cum separator.

\section{Materials and Methods}

Designed and developed a turmeric digger cum separator for harvesting turmeric crop by considering soil, biometric and machine parameters utilizing PTO power of the tractor. The main purpose was to design the machine for harvesting turmeric crop with minimum draft requirement, maximum digging efficiency, low damage to rhizome and less fuel consumption along with greater soil separation at economic cost of operation. The fabricated machine consisted of main frame, gear box housing, power transmission system, depth gauge wheel, digging unit, ground wheel, elevator conveyor system. The machine consisted of a main frame having dimensions 1610 x $1140 \mathrm{~mm}$ for mounting digging blade, vibration unit, power transmission system depth gauge wheel and elevator conveyor systems. Digger blade having length, width and thickness of $1140 \mathrm{x}$ $380 \times 08 \mathrm{~mm}$ respectively. The blade was mounted at an angle of 20 degree with the horizontal. Two depth gauge wheels having diameter of $450 \mathrm{~mm}$ were mounted at both sides of the blade with the spacing between two wheels being $1200 \mathrm{~mm}$. A flat strip was provided immediately after the digging blade for stepping up of soil from the dug crop in the system.

\section{Results and Discussion}

The power transmission system has been made at two stages, first from PTO to machine gear box from which power is transmitted to the conveyor by a belt mechanism system. A machine support over the ground wheel made of pneumatic wheel was provided at centre both sides of the digger machine. The diameter and width of the wheel are 320 and $100 \mathrm{~mm}$ respectively. An elevator conveyor was attached behind the digging unit. The soil-rhizome separating unit consisted of conveyor having dimensions of 1500 x $1080 \mathrm{~mm}$. The conveyor unit consisted of MS rods spaced at $30 \mathrm{~mm}$. The angle of the elevator was kept at 20 degree to the conveying system for separation of soil particles from the rhizome and windrowing in one row at the rear of the machine. The power to the elevator conveyor was provided through a gear box by belt and pulley drive system.

Experiments were conducted according to the plan of the experiment indicated in Table 2. For each test, Matured crop was harvested using experimental set-up of tractor drawn turmeric digger cum separator. The observations on performance parameters were recorded for each test run. All the test runs were replicated thrice to eliminate any experimental bias.

The experiments on test set-up were planned by changing blade type (Strips shape, Inverted $\mathrm{V}$ shape and Crescent shape), rake angle $\left(15^{\circ}\right.$, $20^{\circ}$ and $\left.25^{\circ}\right)$ and speed of operation $(1.5,3.0$ and $4.5 \mathrm{~km} \mathrm{~h}^{-1}$ ) and these independent variables were tested with dependent variables like: draft, digging percentage, per cent damage of rhizome, soil separation index and power requirement. The moisture content of the soil was changed $(12.23 \pm 0.18,14.23 \pm$ 0.35 and $16.28 \pm 0.38 \%$ ) at desired level and depth of operation was also optimized based 
on biometric properties. Soil bulk density was also measured randomly at five different places.

All the experiments were conducted for each one bed lengths which having two rows of turmeric crop for every replication according to the plan of experiments. The first test of experiment was carried out at soil moisture content $16.28 \pm 0.38$ per cent with strips shape blade kept rake angle at 15 degree and the data was recorded at three different speeds of operation. Similarly, tests were conducted for rake angle of 20 and 25 degree and all performance observations were recorded. Each test run was replicated thrice.

Similar set of experiments was carried out using inverted $\mathrm{V}$ blade and crescent blade. Thus a total number of 243 runs were completed and performance data was recorded.

Data were recorded for weight of turmeric rhizomes harvested, weight of turmeric rhizomes not harvested, wt of turmeric rhizomes damaged and weight of soil collected with turmeric rhizomes mass for a test length of $10 \mathrm{~m}$. From this test data, the following performance parameters were determined to evaluate the machine.

\section{Results and Discussion}

Performance evaluation of the developed tractor drawn turmeric digger cum separator was carried out in an experimental field of Khanapur village Parbhani district of Maharashtra State. during 2016-17-18. Results of the experiments on turmeric digger and separator units were the basis for selection of design values of the prototype of tractor drawn turmeric digger cum separator as detailed mentioned, a strips shape blade with rake angle of 20 degree and $3.0 \mathrm{~km} \mathrm{~h}^{-1}$ as selected. Keeping in view of draft, digging efficiency, per cent damage of rhizome, soil separation index and power requirement of the digger machine. Keeping in view the best performance of machine in terms of soil separation index and power requirement. The speed ratio of 1.0 to 1.5 the prototype was kept at 1.25.The overall performance of this mechanism was better in respect of draft, digging efficiency, per cent damage of rhizome, fuel consumption, soil separation index and power requirement.

Testing of the turmeric digger was done according to the BIS code 11235, 1981 and BIS code 13818, 1993 by following the Test Code and procedure as per Regional Network For Agriculture Machinery, Philippines (RNAM 1983) test procedure for root crop digger elevator (Table 1). The following design and operational parameters recommended for the final prototype of turmeric digger cum separator are given in The turmeric digger cum separator was evaluated under optimized parameters viz., strips shape blade, soil moisture content $14.23 \pm 0.35$ per cent, 20 degree rake angle and $3.0 \mathrm{~km} \mathrm{~h}^{-1}$ forward speed. The prototype turmeric digger cum separator was evaluated for 0.5 ha.

The performance parameters and viz., depth of operation, width of operation, speed of operation, draft, digging efficiency, per cent damage of rhizome, fuel consumption, separation index and field capacity were also recorded and presented in Table 4.

It is concluded that in the present study, a tractor drawn turmeric digger cum separator was designed and developed. The developed prototype was tested and the best optimal solution (Table 3) of digging unit was selected strips shape digging blade at three different levels of a forward speed of 1.5, 3.0 and $4.5 \mathrm{~km} \mathrm{~h}^{-1}$. 
Table.1 The detailed specifications of the turmeric digger cum separator

\begin{tabular}{|c|c|c|}
\hline Sr.no & Component & $\begin{array}{l}\text { Dimens } \\
\text { ions }\end{array}$ \\
\hline \multirow[t]{4}{*}{1.} & Digger blade & \\
\hline & a) Length, mm & 380 \\
\hline & b) Width, mm & 1140 \\
\hline & c) Thickness, mm & 08 \\
\hline \multirow[t]{8}{*}{2.} & Separating unit & \\
\hline & a) Length, mm & 3000 \\
\hline & b) Width, mm & 1080 \\
\hline & c) Canvas belt strip width, $\mathrm{mm}$ & 65 \\
\hline & d) Diameter of rod, $\mathrm{mm}$ & 12 \\
\hline & e) Spacing between rods, $\mathrm{mm}$ & 25 \\
\hline & f) Number of rods & 70 \\
\hline & $\begin{array}{l}\text { g) Height of conveyor from ground, } \\
\mathrm{mm}\end{array}$ & $\begin{array}{l}39 \text { front } \\
50 \text { rear }\end{array}$ \\
\hline \multirow[t]{10}{*}{3.} & Power transmission system & \\
\hline & i. Number of flanges in the coupling & 2 \\
\hline & $\begin{array}{l}\text { ii. Diameter of the input to the gear } \\
\text { box, mm }\end{array}$ & 30 \\
\hline & $\begin{array}{l}\text { iii. Length of the input shaft to the } \\
\text { gear box, } \mathrm{mm}\end{array}$ & 480 \\
\hline & iv. Gear reduction in gear box & $1: 2$ \\
\hline & $\begin{array}{l}\text { v. Diameter of the output shaft from } \\
\text { the gear box, mm }\end{array}$ & 35 \\
\hline & $\begin{array}{l}\text { vi. Length of the output shaft from } \\
\text { the gear box, mm }\end{array}$ & 1500 \\
\hline & $\begin{array}{l}\text { vii. Speed reduction by the belt - } \\
\text { pulley }\end{array}$ & $3: 1$ \\
\hline & $\begin{array}{l}\text { viii. Center to center distance } \\
\text { between pulley, } \mathrm{mm}\end{array}$ & 1420 \\
\hline & ix. Number teeth of idler & 10 \\
\hline \multirow[t]{4}{*}{4.} & Main frame & \\
\hline & a) Length, $\mathrm{mm}$ & 1610 \\
\hline & b) Width, mm & 1140 \\
\hline & c) Height, mm & 600 \\
\hline \multirow[t]{4}{*}{5.} & Overall dimensions & \\
\hline & a) Length, $\mathrm{mm}$ & 2000 \\
\hline & b) Width, mm & 1480 \\
\hline & c) Height, mm & 1180 \\
\hline 6. & Weight of the digger machine, $\mathrm{kg}$ & 490 \\
\hline
\end{tabular}


Table.2 Variables selected for the test of turmeric digger cum separator

\begin{tabular}{|c|c|c|c|}
\hline Sr.No & $\begin{array}{l}\text { Parameters } \\
\text { Independent }\end{array}$ & Levels & $\begin{array}{l}\text { Performance parameters to } \\
\text { be measured Dependent }\end{array}$ \\
\hline 1 & $\begin{array}{l}\text { 1. Soil parameter } \\
\text { Moisture Content }(\%) \\
\text { 2. Machine parameter } \\
\text { Rake angle, degree } \\
\text { 3. Tractor parameter } \\
\text { Forward Speed }\left(\mathrm{km} \cdot \mathrm{h}^{-1}\right) \\
\text { 4.Shape of digging blade }\end{array}$ & $\begin{array}{l}12,14,16 \\
15^{\circ}, 20^{\circ}, 25^{\circ} \\
1.5,3.0,4.5 \\
\text { 1.Strips shape } \\
\text { 2.Inverted'V'shape } \\
\text { 3.Crescent shape }\end{array}$ & $\begin{array}{l}\text { Bulk density of soil was } \\
\text { measured at respective soil } \\
\text { moisture content. } \\
\text { 1. Harvesting percentage } \\
\text { 2. Soil separation index } \\
\text { 3. Damage percentage } \\
\text { 4.Power requirement }(\mathrm{kW}) \\
\text { 5.Draft of machine. }\end{array}$ \\
\hline 2 & \multicolumn{3}{|c|}{$\begin{array}{l}\text { Constant parameters } \\
\text { i) Length of blade, } \mathrm{mm} \\
\text { ii) Length of soil separator, } \mathrm{mm}\end{array}$} \\
\hline \multicolumn{4}{|c|}{ - Total number of treatment combinations $=3 \times 3 \times 3 \times 3=81$} \\
\hline
\end{tabular}

Table.3 Best optimal solution of digging unit

\begin{tabular}{|l|l|l|}
\hline Sr.no & Variables & Optimal Values \\
\hline $\mathbf{1}$ & Tool geometry & Strips shape digging blade \\
\hline $\mathbf{2}$ & Optimum soil moisture content & $14.23 \pm 0.35$ per cent \\
\hline $\mathbf{3}$ & Rake angle & $20^{\circ}$ \\
\hline $\mathbf{4}$ & speed of operation & $3.0 \mathrm{~km} \mathrm{~h}^{-1}$ \\
\hline
\end{tabular}

Table.4 Performance values of final recommended Strips shape digging blade for turmeric digger machine

\begin{tabular}{|c|l|c|}
\hline Sr.no. & \multicolumn{1}{|c|}{ Performance parameters } & Performance value Range \\
\hline $\mathbf{1}$ & Digging efficiency, per cent & $\mathbf{9 7 . 3 5}$ \\
\hline $\mathbf{2}$ & Soil Separation index, per cent & $\mathbf{0 . 2 4}$ \\
\hline $\mathbf{3}$ & Turmeric rhizome damage, per cent & 3.34 \\
\hline $\mathbf{4}$ & Depth of cut in mm & $\mathbf{2 1 5}$ \\
\hline $\mathbf{5}$ & Fuel consumption, $\mathrm{l} / \mathrm{h}$ & $\mathbf{6 . 1 2}$ \\
\hline $\mathbf{6}$ & Draft, N & $\mathbf{2 1 9 9}$ \\
\hline $\mathbf{7}$ & Field capacity, ha/h & $\mathbf{0 . 4 7}$ \\
\hline $\mathbf{8}$ & Power requirement, $\mathrm{kW}$ & $\mathbf{0 . 9 1 - 3 . 6 8}$ \\
\hline
\end{tabular}




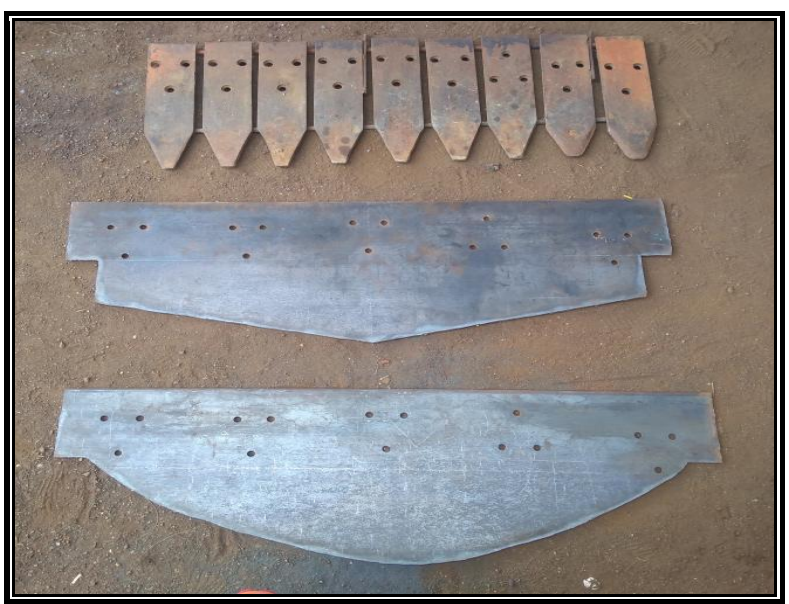

Plate no. 1 Different shape of blades

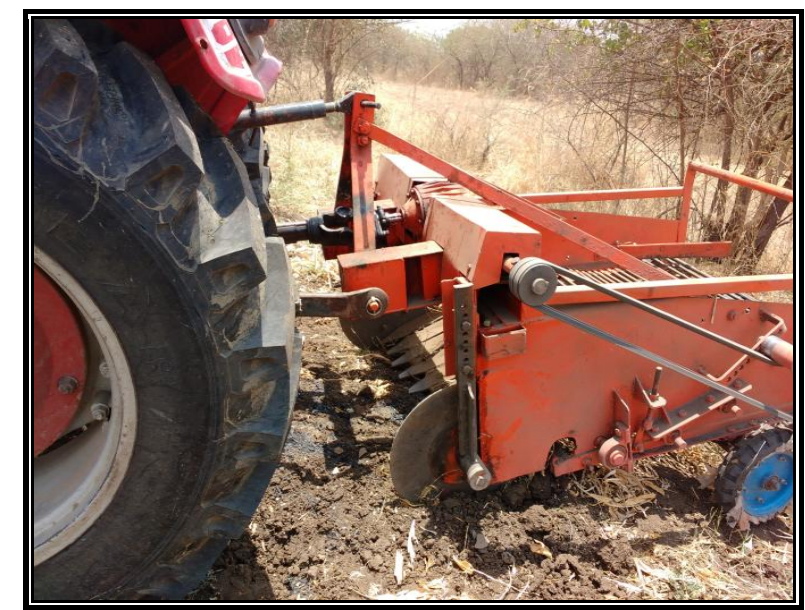

Plate no. 2 Field evaluation of Turmeric digger

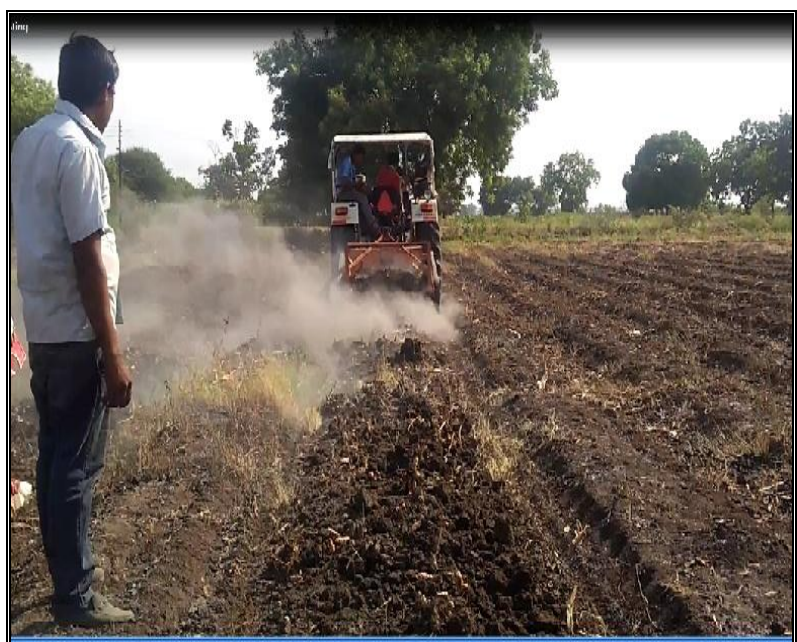

Plate no. 3 Field testing of developed turmeric digger cum separator 


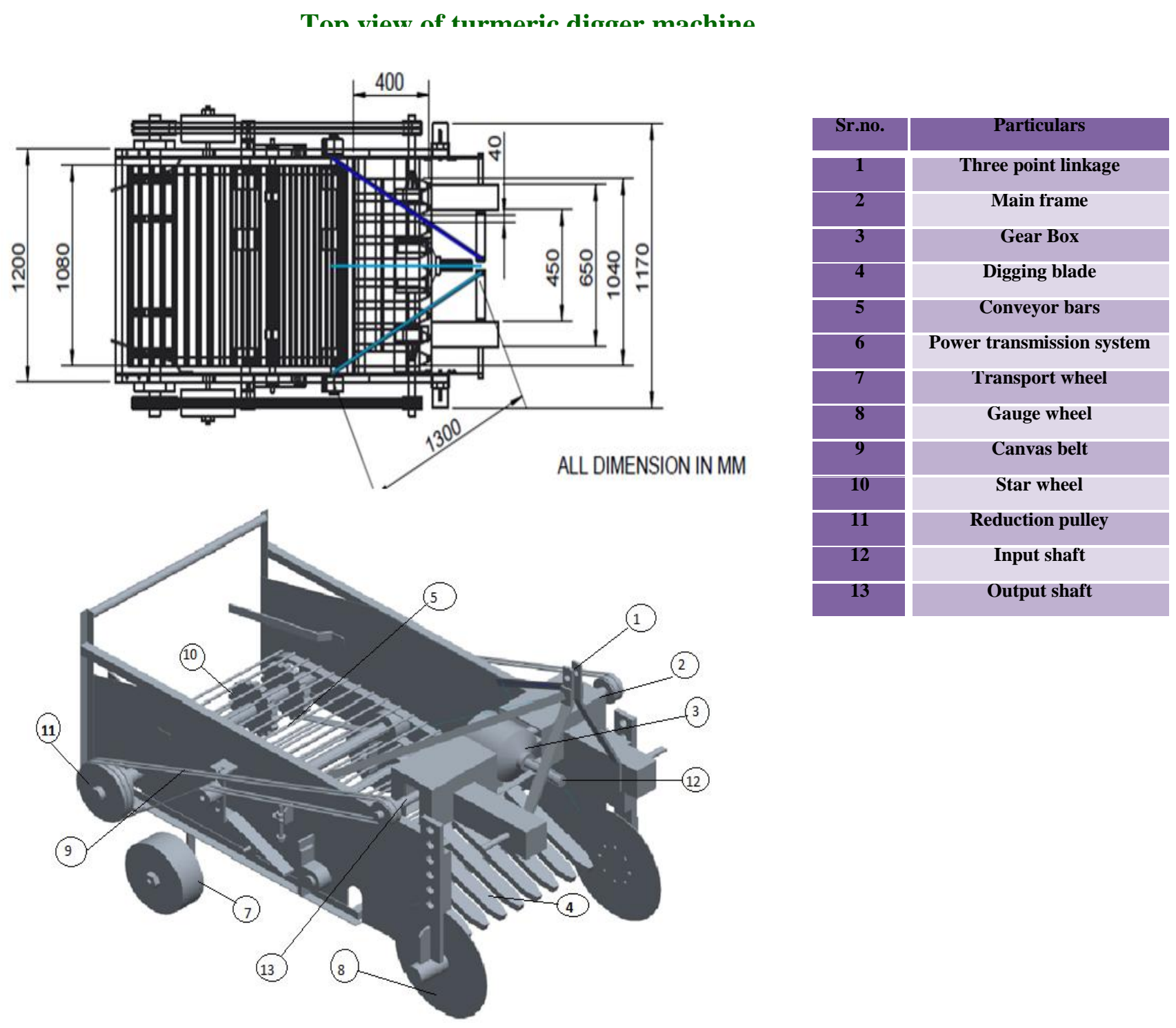

Isometric view of turmeric digger cum separator

The draft and power requirement for harvesting turmeric crop using digger cum separator was measured and it was found to be $2199 \mathrm{~N}$ and $0.91 \mathrm{~kW}$ respectively. Fuel consumption for particular operation was observed to be $6.121 \mathrm{~h}^{-1}$. turmeric digger cum separator was calculated respectively. The field capacity was to be found 0.47 ha $\mathrm{h}^{-1}$ respectively.

The performance of the final developed turmeric digger cum separator was recorded to be digging efficiency 97.35 per cent, Damage percentage 3.34 per cent, Soil separation Index 0.24 per cent, fuel consumption $6.12 \mathrm{l} / \mathrm{h}$, draft $2199 \mathrm{~N}$ and Power requirement $0.91 \mathrm{~kW}$.

\section{References}

Anonymous, 2007. Significance of turmeric as spice in India. Dolcas Biotech LLC, pp 1-11.

Devi, K. S. P. and Sangamithra, A. (2011). 
Turmeric - Indian Saffron, Technical

Kadte, A.J., D.S. Perke and P. S. Kale (2018)

Economics of Turmeric Production in Sangli District of Maharashtra, India. Int.J.Curr.Microbiol.App.Sci (2018) Special Issue-6: 2279- 2284 Bulletin: Science Tech Entrepreneur. pp. 1-7.

Kawale Nagendra et al., (2018) Development and Evaluation of Tractor Drawn Ginger Harvester cum Elevator International Journal of Current Microbiology and Applied Sciences Volume 7 Number 12
Parthasarathy, V. A. and Kandiannan, K. (2007). Spices and Condiments, IISR, Calicut.

Rattan, R. S., Korla, B. N. and Dohroo, N. P., (1988), Performance of ginger varieties under Solan conditions of Himachal Pradesh. Proceedings of National Seminar on Chillies, Ginger and Turmeric., pp 71-73.

Sharma, A. P. and Verma, S. R., 1986, Design, development and field evaluation of an oscillatory potato digger. AMA., 17(3): 60-62.

\section{How to cite this article:}

Shailaja Deshvena, R.T. Ramteke and Solanki, S.N. 2019. Development and Performance Evaluation of Tractor Drawn Turmeric Digger cum Separator. Int.J.Curr.Microbiol.App.Sci. 8(02): 1053-1061. doi: https://doi.org/10.20546/ijcmas.2019.802.124 